\title{
Gaya Bahasa Asonansi dan Aliterasi pada Antologi Puisi Romances Sans Paroles
}

\author{
Icha Priliskha Yunisty $^{1}$, Nurul Hayana ${ }^{2}$, Yuliarti Mutiarsih ${ }^{3}$ \\ 1,3 Pendidikan Bahasa Prancis, Universitas Pendidikan Indonesia \\ ${ }^{2}$ Hubungan Internasional, Universitas Padjadjaran \\ ichapriliskha96@upi.edu
}

\begin{abstract}
This research aims to explain the analysis figure of speech of assonance et alliteration in poems anthology by Paul Verlaine. The research questions discussed in this research are how the assonance and the alliteration found in those poems by focusing on the repetition of vowels and consonants phonemes in an array. The method used in this research is descriptive-qualitative, by analyzing data contained in the poetry anthology Romances Sans Paroles in the form of sentences. The repetition of phonemes both assonance and alliteration was encountered 137 times. 61 assonances and 76 alliterations were found. The data is dominated by the phoneme $[R]$ which is a type of vibrating shear consonant that found 11 times.
\end{abstract}

Keywords: Assonance; alliteration; poem.

\section{Intisari}

Penelitian ini bertujuan untuk menjelaskan gaya bahasa asonansi dan aliterasi pada antologi puisi Romances sans Paroles dari pengarang Paul Verlaine. Permasalahan yang dibahas dalam penelitian ini adalah bagaimana asonansi dan aliterasi ditemukan dalam puisi-puisi tersebut. Fokus dari penelitian ini adalah repitisi fonem vokal dan konsonan pada suatu larik puisi. Metode yang digunakan dalam penelitian ini adalah deskriptif kualitatif yaitu dengan menganalisis data yang ada pada antologi puisi Romance Sans Paroles lalu hasil analisis dipaparkan berupa kalimat. Hasil Penelitian menunjukkan bahwa asonansi dan aliterasi ditemukan di semua judul dari puisi Romance Sans Paroles. Pengulangan fonem-fonem baik secara asonansi dan aliterasi ditemui sebanyak 137 kali. Ditemukan 61 asonansi dan 76 aliterasi. Data didominasi oleh fonem [R] yang merupakan tipe konsonan geseran bergetar ditemukan sebanyak 11 kali.

Kata kunci: Asonansi; aliterasi; puisi.

\section{Pendahuluan}

Bahasa adalah tanda yang digunakan dan dipahami oleh sebuah kelompok masyarakat sebagai sistem komunikasi. Menurut Chaer (2011) Bahasa adalah sistem lambang berupa bunyi yang arbitrer, yang digunakan oleh anggota suatu masyarakat untuk bekerja sama, berinteraksi, dan mengidentifikasikan diri. Setiap kelompok masyarakat mempunyai simbol tersendiri yang digunakan dalam proses komunikasi secara verbal dan non verbal yang diatur dalam suatu payung kajian ilmu yaitu linguistik. 
Icha Priliskha Y., Nurul Hayana, Yuliarti Mutiarsih, Gaya Bahasa Asonansi dan Aliterasi pada Antologi Puisi Romances Sans Paroles

Linguistik terbagi atas dua bagian: bahasa lisan sebagai objek utama dan bahasa tulis merupakan objek kedua. Meskipun bahasa terbagi atas objek utama dan kedua, bahasa tulis dalam kehidupan modern selalu mengambil peranan yang sangat penting karena menunjukkan bukti sejarah sementara itu bahasa lisan dapat saja hilang. Bahasa tulis bisa ditemukan dalam berbagai bentuk: teks seperti artikel, jurnal, karya ilmiah, kitab suci, manuskrip, novel, dll. Namun, dalam karya sastra, khususnya puisi, keseimbangan antara bahasa lisan dan tulis harusnya sama, karena keduanya digunakan untuk menambah harmoni pada puisi. Puisi membantu untuk berkomunikasi tentang subyek yang sensitif dengan penggunakan bahasa khusus: yaitu gaya bahasa. Gaya bahasa dalam puisi ditambahkan sebagai kombinasi dari unsur-unsur keindahan kata-kata karena puisi merupakan sebuah karya sastra yang menekankan keindahan bahasa sebagai objek pikiran imajinatif dari pengarangnya. Sebagaimana diungkapkan oleh Waluyo (2002) mengatakan bahwa puisi adalah suatu bentuk karya sastra yang mengungkapkan pikiran dan perasaan penyair secara imajinatif dan disusun dengan mengkonsentrasikan semua kekuatan bahasa dengan pengkonsentrasian struktur fisik dan struktur batinnya. Tak hanya dari segi bahasa tulis, puisi juga dapat dinikmati dari resitasi pembacanya, melalui artikulasi dan intonasi yang pas maka puisi akan tersampaikan dengan baik dan indah. Hal ini diungkapkan juga oleh Vaillant (2005:17) "comme poésie est avant tout la musique" yang artinya puisi adalah awalan dari seluruh musik, dia menemukan tempatnya sendiri di dalam lagu dan ide-ide tersalurkan dengan cara puitis.

Gaya bahasa yang digunakan sebagai penyelaras bahasa tulis dan lisan dalam puisi adalah gaya bahasa asonansi dan aliterasi, penyair menggunakan gaya tersebut untuk menambah keindahan puisi mereka dan menciptakan tekanan atau perasaan dengan menyoroti unsur-unsur fonetik. Perbedaan bunyi pada setiap fonem yang tersusun akan menciptakan tekanan tertentu dan efek bunyi tersebut akan membawa pembaca ke dalam suasana puisinya, dan memahami gaya bahasa berarti memahami salah satu teknik dalam penciptaan karya sastra. Terdapat dua jenis gaya bahasa bunyi, atau bisa disebut juga majas perulangan, yaitu majas asonansi, dan aliterasi. Asonansi adalah pengulangan vokal pada satu larik, dan aliterasi adalah pengulangan konsonan, apabila tidak ditemukan asonansi atau aliterasi pada suatu larik maka bisa dilihat pada satu bait puisi. Dalam penelitian ini akan dibahas bagaimana asonansi dan aliterasi terbentuk, juga jenis fonem apa yang akan berperan di dalam puisi-puisi tersebut. 
Icha Priliskha Y., Nurul Hayana, Yuliarti Mutiarsih, Gaya Bahasa Asonansi dan Aliterasi pada Antologi Puisi Romances Sans Paroles

Permasalahan terjadi pada pembelajar bahasa Perancis di Indonesia, perbedaan cara pengucapan sering sekali mengakibatkan kesalahan dalam mengucapkan kalimat, apabila kesalahan tersebut terjadi pada pembacaan puisi maka kesan yang tersirat dalam suatu puisi tidak akan ditemukan akibatnya harmoni akan terasa berbeda. Akibat kesalahan yang terjadi dalam menyampaikan harmoni pada puisi Perancis yang dilakukan para pembelajar bahasa Perancis di Indonesia, maka dari itu penting untuk dilakukan studi mengenai asonansi dan aliterasi dalam karya sastra puisi.

\section{Metode Penelitian}

Penelitian ini merupakan penilitian deskriptif kualitatif dengan metode pengambilan data random sampling berupa transkrip fonetik dari enam belas judul puisi dari antologi puisi Romance Sans Parole karya Paul Verlaine yaitu : (1) Ariettes Oubliées I, (2) Ariettes Oubliées II, (3) Ariettes Oubliées III, (4) Ariettes Oubliées IV, (5) Ariettes Oubliées V, (6) Ariettes Oubliées VI, (7) Ariettes Oubliées VII, (8) Ariettes Oubliées VIII, (9) Ariettes Oubliées IX, (10) Walcourt, (11) Charleroi, (12) Bruxelles-Simple Fresque I, (13) Bruxelles-Simple Fresque II, (14) Bruxelles-Chevaux de Bois, (15) Malines, (16) Green.

Data dikumpulkan dengan menggunakan teknik membaca, mencatat, mentraskripkan fonetik, dan mengklasifikasikan. Kemudian, data dianalisis dan dikategorikan, hasil analisis kselanjutnya disajikan ke dalam instrumen penelitian berupa tabel data untuk mempermudah pengkatagorikan dan diisi menggunakan kata-kata. Teknik analisis dalam penelitian ini meliputi; 1. Memilih salah satu karya puisi Paul Verlaine sebagai korpus penelitian, 2. Membaca puisi-puisi pada antologi Romance Sans Paroles beberapa kali, 3. Membuat traskrip fonetik, 4. Menganalisis tipe gaya bahasa, 5. Mengkatagorikan data seusai tema, 6. Menyimpulkan data menggunakan instrumen penelitian.

Adapun validitas dan reabilitas digunakan untuk memvalidasi data temuan dengan menganalisis dan membaca konteks pada teks, lalu transkrip fonetik divalidasi pada laman www.easypronunctiation.com. Situs tersebut merupakan situs untuk mengubah hurufhuruf latin menjadi transkrip fonetik berstandar IPA sesuai dengan bahasa yang dipilih, kemudian hasil analisis didiskusikan dengan dosen ahli. 


\section{Hasil dan Pembahasan}

Dalam pembahasan ini akan diuraikan bagaimana gaya bahasa asonansi dan alitersi yang ditemukan pada 16 judul puisi dari pengarang Prancis Paul Verlaine dalam antologi puisi berjudul Romances sans Paroles melalui transkrip fonetik.

\section{Hasil}

Berdasarkan penelitian yang telah dilakukan, berikut temuan yang penulis sajikan dalam tabel di bawah ini

Tabel 1. Rekapitulasi data analisis

\begin{tabular}{|c|c|c|c|c|}
\hline \multirow[t]{2}{*}{ No } & \multirow[t]{2}{*}{ Judul } & \multicolumn{2}{|r|}{ Tipe } & \multirow[t]{2}{*}{ Dominasi } \\
\hline & & Asonansi & Aliterasi & \\
\hline (1) & (2) & (3) & (4) & (5) \\
\hline 1 & Ariettes Oubliées I & 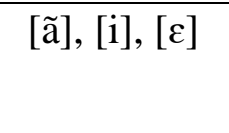 & $\begin{array}{l}{[1],[s],[\mathrm{f}],[\mathrm{R}],[\mathrm{s}],[\mathrm{j}]} \\
{[\mathrm{n}]}\end{array}$ & {$[\tilde{a}],[R]$} \\
\hline 2 & Ariettes Oubliées II & $\begin{array}{c}\mathrm{y}],[\tilde{\mathrm{o}}],[\mathrm{u}], \\
{[\varepsilon],[\varnothing], \text { et }} \\
{[\mathrm{o}]}\end{array}$ & {$[\mathrm{R}],[\mathrm{t}]$} & {$[\mathrm{R}]$} \\
\hline 3 & Ariettes Oubliées III & [œ] et $[\mathrm{\Psi}]$ & {$[\mathrm{R}],[\mathrm{l}],[\mathrm{k}]$ dan $[\mathrm{p}]$.} & {$[\mathrm{R}]$} \\
\hline 4 & Ariettes Oubliées IV & 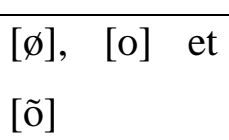 & {$[\mathrm{s}],[\mathrm{m}],[\mathrm{j}]$ dan $[\mathrm{R}]$} & {$[\mathrm{R}]$} \\
\hline 5 & Ariettes Oubliées V & $\begin{array}{l}{[\tilde{\varepsilon}]} \\
{[a] \text { et }[o]}\end{array}$ & $\begin{array}{l}\text { [R] } \\
{[\mathrm{j}],[\mathrm{k}][\mathrm{s}] \text { dan [f]. }}\end{array}$ & {$[\mathrm{R}]$} \\
\hline 6 & Ariettes Oubliées VI & $\begin{array}{l}\partial],[\varepsilon],[y], \\
{[u],[a],[o]}\end{array}$ & $\begin{array}{l}{\left[\int\right],[\mathrm{b}],[1],[\mathrm{m}],[\mathrm{s}],} \\
{[\mathrm{R}],[\mathrm{v}],[\mathrm{b}],[\mathrm{p}],[\mathrm{t}] .}\end{array}$ & $\begin{array}{c}\text { Tidak ditemukan } \\
\text { fonem yang } \\
\text { mendominasi }\end{array}$ \\
\hline 7 & Ariettes Oubliées VII & [ə] et [i] & $\begin{array}{c}{[\mathrm{t}],[\mathrm{m}],[\mathrm{k}],[\mathrm{s}],[\mathrm{R}],} \\
{[\mathrm{l}] .}\end{array}$ & [m] dan [1] \\
\hline 8 & $\begin{array}{c}\text { Arriettes Oubliées } \\
\text { VIII }\end{array}$ & $\begin{array}{l}\varepsilon],[\mathrm{a}],[\mathrm{e}] \\
\text { et }[\mathrm{u}]\end{array}$ & {$[\mathrm{n}],[1],[\mathrm{R}]$, dan $[\mathrm{k}]$} & [1] \\
\hline
\end{tabular}




\begin{tabular}{|c|c|c|c|c|}
\hline 9 & Ariettes Oubliées IX & [e] et $[\varepsilon]$. & {$[\mathrm{R}],[1]$, dan $[3]$} & $\begin{array}{c}\text { Tidak ditemukan } \\
\text { fonem yang } \\
\text { mendominasi }\end{array}$ \\
\hline 10 & Walcourt & [i] et $[\varepsilon]$ & {$[\mathrm{R}],[\mathrm{f}],[\mathrm{z}]$, et $[\mathrm{g}]$} & {$[\mathrm{R}]$} \\
\hline 11 & Charleroi & $\begin{array}{c}{[\tilde{o}],[\varepsilon] \text { et }} \\
{[\varnothing]}\end{array}$ & $\begin{array}{c}{[\mathrm{R}],[\mathrm{k}],[\mathrm{s}],[\mathrm{l}],[\mathrm{z}],} \\
{[3], \text { dan }[\mathrm{t}]}\end{array}$ & [õ] dan $[R]$ \\
\hline 12 & $\begin{array}{c}\text { Bruxelles -Simples } \\
\text { Fresques I }\end{array}$ & $\begin{array}{c}{[\mathrm{e}],[\tilde{a}] \text { et }} \\
{[\varepsilon]}\end{array}$ & {$[\mathrm{R}],[\mathrm{d}],[\mathrm{s}]$, dan $[\mathrm{l}]$} & {$[\tilde{a}],[R],[s]$} \\
\hline 13 & $\begin{array}{c}\text { Bruxelles -Simples } \\
\text { Fresques II }\end{array}$ & [e] et $[\varepsilon]$ & {$[1],[\mathrm{s}],[\mathrm{j}],[\mathrm{R}],[\mathrm{v}]$} & {$[1]$} \\
\hline 14 & $\begin{array}{c}\text { Bruxxelles - Chevaux } \\
\text { de Bois }\end{array}$ & $\begin{array}{c}\text { [o], [oe], } \\
{[\tilde{o}],[\mathrm{a}],[\tilde{a}],} \\
{[\mathrm{i}],[\mathrm{y}] \text { et }[\mathrm{u}]}\end{array}$ & $\begin{array}{c}{[1],[\mathrm{R}],[\mathrm{s}],[\mathrm{t}],[\mathrm{m}],} \\
{[\mathrm{d}]}\end{array}$ & [a] dan [R] \\
\hline 15 & Malines & $\begin{array}{l}{[\varepsilon],[\mathrm{e}],[\tilde{a}],} \\
{[\mathrm{e}],[\tilde{\varepsilon}],[\tilde{\mathrm{o}}]}\end{array}$ & {$[\mathrm{R}],\left[\int\right],[\mathrm{b}],[\mathrm{l}]$ et $[\mathrm{s}]$} & [e] dan $[\mathrm{R}]$ \\
\hline 16 & Green & $\begin{array}{l}{[\mathrm{i}],[\mathrm{o}],[\tilde{\varepsilon}],} \\
{[\tilde{o}],[\mathrm{e}], \text { et }} \\
{[ə]}\end{array}$ & $\begin{array}{c}{[\mathrm{f}],[\mathrm{R}],[\mathrm{v}],\left[\int\right],[\mathrm{p}],} \\
{[\mathrm{s}]}\end{array}$ & {$[\mathrm{R}]$} \\
\hline & Total & 61 kali & 76 kali & $\begin{array}{l}\text { Didominasi oleh } \\
\text { [R] sebanyak } 11 \\
\text { kali }\end{array}$ \\
\hline
\end{tabular}

Di dalam penelitian ini, terdapat enam belas judul dari antologi puisi Romances Sans Paroles karya Paul Verlaine, antara lain: Ariettes Oubliées I, Ariettes Oubliées II, Ariettes Oubliées III, Ariettes Oubliées IV, Ariettes Oubliées V, Ariettes Oubliées VI, Ariettes Oubliées VII, Arriettes Oubliées VIII, Ariettes Oubliées IX, Walcourt, Charleroi, Bruxelles -Simples Fresques I, Bruxelles -Simples Fresques II, Bruxxelles -Chevaux de Bois, Malines, Green.

Dari analisis yang telah dilakukan, dapat disimpulkan bahwa asonansi dan aliterasi ditemukan pada semua judul puisi dengan fonem [R] yang mendominasi. 
Berdasarkan data di atas, adanya gaya bahasa asonansi sebanyak $61 \mathrm{kali}$, dan gaya bahasa aliterasi sebanyak 76 kali, dengan dominasi oleh repitisi atau aliterasi pada fonem $[\mathrm{R}]$ yang merupakan tipe konsonan geseran bergetar. Aliterasi yang dtemukan dari analisis 16 judul puisi dari antologi Romances Sans Paroles berrguna untuk memberi tekanan pada ritma dan suara yang akan dihasilkan dalam pembacaan puisi.

\section{Pembahasan}

Perbedaan pengucapan antara bahasa Indonesia dan bahasa Prancis akan menyebabkan interferensi fonologi bagi penuturnya, sehingga sebelum memulai menganalisa gaya bahasa asonansi dan aliterasi perlu diketahui jenis-jenis fonem yang terdapat dalam bahasa Prancis. Fonem dalam bahasa Prancis terdiri dari vokal oral, vokal sengau, konsonan dan semi konsonan. Untuk lebih jelasnya dapat dilihat pada tabel di bawah ini. Berikut daftar bunyi vokal dan konsonan dalam bahasa Prancis

Tabel. 1Vokal dalam bahasa Prancis

\begin{tabular}{|c|c|c|c|c|}
\hline & $\begin{array}{l}\text { Suara } \\
\text { bagian } \\
\text { depan } \\
\text { (Antérieur } \\
\text { s écartées) }\end{array}$ & $\begin{array}{l}\text { Suara bagian } \\
\text { depan } \\
\text { membulat ( } \\
\text { antérieurs } \\
\text { arrondies) }\end{array}$ & $\begin{array}{l}\text { Suara bagian } \\
\text { belakang ( } \\
\text { Postérieur } \\
\text { écartées) }\end{array}$ & $\begin{array}{l}\text { Suara bagian } \\
\text { belakang } \\
\text { membulat } \\
\text { (Postérieurs } \\
\text { arrondies) }\end{array}$ \\
\hline \multicolumn{5}{|l|}{ ORAL (ORALES) } \\
\hline $\begin{array}{l}\text { Sangat tertutup } \\
\text { (Très fermées) }\end{array}$ & [i] & {$[\mathrm{y}]$} & & {$[\mathrm{u}]$} \\
\hline Tertutup (Fermées) & [e] & {$[\varnothing]$} & & [o] \\
\hline Madya (Moyenne) & & [ə] & & \\
\hline Terbuka (Ouverts) & {$[\varepsilon]$} & [œ] & & [o] \\
\hline $\begin{array}{l}\text { Terbuka lebar (Très } \\
\text { ouverts) }\end{array}$ & [a] & & {$[a]$} & \\
\hline \multicolumn{5}{|l|}{$\begin{array}{l}\text { SUARA SENGAU } \\
(N A S A L E S)\end{array}$} \\
\hline $\begin{array}{l}\text { Sangat tertutup } \\
\text { (Trèsfermées) }\end{array}$ & & & & \\
\hline
\end{tabular}




\begin{tabular}{|l|c|c|c|c|}
\hline Tertutup (Fermées) & & & {$[\tilde{0}]$} \\
\hline Madya (Moyenne) & & & & \\
\hline Terbuka (Ouverts) & {$[\tilde{\varepsilon}]$} & {$[0 \tilde{]}]$} & & \\
\hline $\begin{array}{l}\text { Terbuka lebar (Très } \\
\text { ouvertes) }\end{array}$ & & & {$[\tilde{\alpha}]$} & \\
\hline
\end{tabular}

Tabel. 2 Konsonan dalam bahasa Prancis

\begin{tabular}{|c|c|c|c|}
\hline $\begin{array}{l}\text { TERHAMBAT ( } \\
\text { OCCLUSIVES) }\end{array}$ & Labial (Labiales) & $\begin{array}{l}\text { Dental } \\
\text { (Dentales) }\end{array}$ & Palatales/vélaires \\
\hline $\begin{array}{l}\text { Tak } \\
\text { (Sourdes) }\end{array}$ & [p] & {$[\mathrm{t}]$} & {$[\mathrm{k}]$} \\
\hline \multirow[t]{2}{*}{ Bersuara (Sonores) } & [b] & [d] & {$[\mathrm{g}]$} \\
\hline & & & {$[n]$} \\
\hline Sengau (Nasales) & {$[\mathrm{m}]$} & {$[\mathrm{n}]$} & \\
\hline $\begin{array}{l}\text { GESERAN } \\
(C O N S T R I C T I V E S)\end{array}$ & $\begin{array}{l}\text { Labiodental ( } \\
\text { Labiodentales) }\end{array}$ & $\begin{array}{c}\text { Alveolar } \\
\text { (Alvéolaires) }\end{array}$ & $\begin{array}{c}\text { Prepatal ( } \\
\text { Prépatales/bilabi } \\
\text { ales) }\end{array}$ \\
\hline $\begin{array}{l}\text { Tak } \\
\text { (Sourdes) }\end{array}$ & {$[\mathrm{f}]$} & {$[\mathrm{s}]$} & {$\left[\int\right]$} \\
\hline \multirow[t]{2}{*}{ Bersuara (Sonores) } & [v] & {$[\mathrm{z}]$} & [3] \\
\hline & & $\begin{array}{c}\text { Alveolar } \\
\text { (Alvéolaire) }\end{array}$ & $\begin{array}{c}\text { Dorso-velar } \\
\text { (Dorsovélaire) }\end{array}$ \\
\hline Sampingan (Latérale) & & {$[1]$} & \\
\hline Bergetar (Vibrant) & & & {$[\mathrm{R}]$} \\
\hline \multirow[t]{2}{*}{$\begin{array}{l}\text { SEMI KONSON } \\
\text { SEMI-CONSONNES }\end{array}$} & $\begin{array}{c}\text { Patal } \\
\text { (Patale) }\end{array}$ & $\begin{array}{c}\text { Palatal } \\
\text { (Palatale/labialisée })\end{array}$ & $\begin{array}{c}\text { Velar } \\
\text { (Vélaire) }\end{array}$ \\
\hline & {$[\mathrm{j}]$} & {$[\mathrm{y}]$} & [w] \\
\hline $\begin{array}{l}\text { TERHAMBAT ( } \\
\text { OCCLUSIVES) }\end{array}$ & Labial (Labiales) & $\begin{array}{l}\text { Dental } \\
\text { (Dentales) }\end{array}$ & Palatales/vélaires \\
\hline $\begin{array}{ll}\text { Tak } & \text { bersuara } \\
\text { (Sourdes) } & \end{array}$ & [p] & {$[\mathrm{t}]$} & {$[\mathrm{k}]$} \\
\hline \multirow[t]{2}{*}{ Bersuara (Sonores) } & [b] & [d] & {$[\mathrm{g}]$} \\
\hline & & & {$[\eta]$} \\
\hline $\begin{array}{l}\text { GESERAN } \\
\text { (CONSTRICTIVES) }\end{array}$ & $\begin{array}{l}\text { Labiodental ( } \\
\text { Labiodentales) }\end{array}$ & $\begin{array}{c}\text { Alveolar } \\
\text { (Alvéolaires) }\end{array}$ & $\begin{array}{c}\text { Prepatal ( } \\
\text { Prépatales/bilabi } \\
\text { ales) }\end{array}$ \\
\hline
\end{tabular}




\begin{tabular}{|l|c|c|c|}
\hline $\begin{array}{l}\text { Tak bersuara } \\
\text { (Sourdes) }\end{array}$ & {$[\mathrm{f}]$} & {$[\mathrm{s}]$} & {$[\mathrm{J}]$} \\
\hline Bersuara (Sonores) & {$[\mathrm{v}]$} & {$[\mathrm{z}]$} & {$[3]$} \\
\hline & & $\begin{array}{c}\text { Alveolar } \\
\text { (Alvéolaire) }\end{array}$ & $\begin{array}{c}\text { Dorso-velar } \\
\text { (Dorsovélaire) }\end{array}$ \\
\hline Sampingan (Latérale) & & {$[1]$} & {$[\mathrm{R}]$} \\
\hline Bergetar (Vibrant) & Patal & Palatal & $\begin{array}{c}\text { Velar } \\
(\text { Vélaire })\end{array}$ \\
\hline \hline SEMI KONSON & $($ Patale) & $($ Palatale/labialisée $)$ & {$[\mathrm{w}]$} \\
\hline (SEMI-CONSONNES) & {$[\mathrm{j}]$} & {$[\mathrm{y}]$} & \\
\cline { 2 - 5 } & & & \\
\hline
\end{tabular}

\section{Asonansi}

Menurut Nayrolles (1996:33) On appelle assonance est la répétition d'une ou plusieurs voyelles à l'intérieur d'un vers, yang artinya asonansi adalah pengulangan satu atau lebih huruf vokal dalam satu bait,. Asonansi merupakan bagian dari bahasa yag menggunakan struktur fonem vokal sebagai fokus utamanya. Pengulangan vokal tersebut akan muncul pada suatu baris puisi yang berdekatan. Sejalan dengan itu, Cathrine M.Grisé (2002 : 59) menyebutkan bahwa L'assonance au sens strict du terme est la répétition de la même voyelle dans la dernière syllabe des mots. Bahwa asonansi dalam arti sempit merupakan pengulangan vokal yang sama dalam suku kata terakhir.

Pada vokal oral sangat tertutup

Tournez, tournez! le ciel en velours

(tuRne tuRne lə sjel $\tilde{\varepsilon}$ vəlüR)

(Verlaine, Cheveaux de Bois dalam antologi Romance Sans Paroles)

Pada larik di atas ditemukan pengulangan vokal $[\mathrm{u}]$. Vokal $[\mathrm{u}]$ marupakan vokal dari tipe sangat tertutup dengan pengucapan melalui suara bagian belakan yang membulat (Postérieurs arrondies).

Pada vokal oral tertutup

Soyons deux enfants, soyons deux jeunes filles [swajõ døzãfã swajõ dø 3øn fij] 
(Verlaine, Arièttes Oubliées III dalam antologi Romance Sans Paroles)

Adanya pengulangan vokal $[\varnothing]$ pada larik tersebut. Vokal $[\varnothing]$ merupakan bagian dari vokal tertutup dan apabila ditinjau dari gerakan lidah maka vokal tersebut masuk ke dalam tipe suara bagian depan yang membulat (antérieurs arrondies), cara pengucapannya yaitu dengan membunyikan suara seperti di antara vokal [o] dan [u].

Pada vokal oral madya

Qu'est-ce que c'est que ce berceau soudain

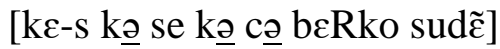

(Verlaine, Arièttes Oubliées V dalam antologi Romance Sans Paroles)

Contoh di atas terlihat adanya pengulangan vokal [ə]. Vokal tersebut termasuk dalam jenis vokal oral madya dengan arti ketika pengucapannya bentuk bibir tidak terbuka dan tidak pula tertutup, atau setengah terbuka dan setengah tertutup. Suara yang dihasilkan akan berada pada bagian depan yang membulat (antérieur arrondie).

Pada vokal oral terbuka

Tandis qu'avec un très léger bruit d'aile

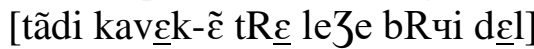

(Verlaine, Arièttes Oubliées V dalam antologi Romance Sans Paroles)

Vokal $[\varepsilon]$ merupakan vokal oral terbuka, dengan arti ketika mengucapkan buny terbut maka yang terjadi adalah mulut terbuka lebar. Namun tidak terlalu lebar dan suara akan dihasilkan pada bagian depan mulut (Antérieur écartée). Contoh di atas merupakan asonansi atau pengulangan vokal untuk bunyi $[\varepsilon]$.

Pada vokal oral terbuka lebar

Triste à peine tant s'effacent

[tRist a pen tã sefás]

(Verlaine, Bruxelles-Simples Fresques dalam antologi Romance Sans Paroles) 
Pada larik tersebut terdapat pengulangan vokal [a], vokal tersebut merupakan vokal yang jika dilafalkan akan membuka mulut yang lebar, dan akan menghasilkan suara pada mulut bagian depan (antérieur écarté).

Pada vokal sengau tertutup

Chaque wagon est un salon

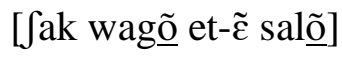

(Verlaine, Malines dalam antologi Romance Sans Paroles)

Terlihat adanya pengulangan vokal nasal [õ] yang merupakan vokal sengau, artinya ketika mengucapkannya adanya udara yang keluar melalui hidung. Vokal nasal [õ] merupakan jenis vokal nasal tertutup dan suara yang dihasilkan akan terasa pada bagian mulut belakang dan suara yang bulat.(postérieur arrondie).

Pada vokal sengau terbuka

Que le vent du matin vient glacer à mon front.

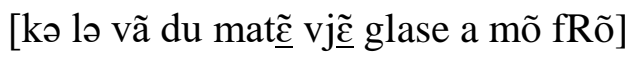

(Verlaine, Green dalam antologi Romance Sans Paroles)

Contoh di atas merupakan asonansi atau pengulangan vokal pada bunyi $[\tilde{\varepsilon}]$, merupakan tipe fonem vokal nasal atau sengau yang jika diucapkan maka bibir akan terbuka. Namun tidak terlalu lebar, napas yang dihembuskan melalui hidung, dan juga terdengar suara yang berasal dari hidung, seperti orang yang sedang terkena flu. Oleh sebab itu fonem $[\tilde{\varepsilon}]$ termasuk dalam bunyi suara bagian depan (antérieur écartée).

Pada vokal sengau terbuka lebar

D'astres en or se vêt lentement.

[dastR ãn-oR sə ve lãtəmã]

(Verlaine, Bruxelles-Chevaux de Bois dalam antologi Romance Sans Paroles)

Pada larik di atas ditemukan adanya pengulangan vokal untuk jenis sengau [ã] sebanyak tiga kali, cara mengucapkannya yaitu dengan pengucapan suara bagian belakang (postérieur écartée) dan mulut yang terbuka lebar.

\section{Aliterasi}


Icha Priliskha Y., Nurul Hayana, Yuliarti Mutiarsih, Gaya Bahasa Asonansi dan Aliterasi pada Antologi

Puisi Romances Sans Paroles

Aliterasi memiliki fungsi yang kuat sebagai harmoni yang imitatif; kadang dianggap sebagai salah satu jenis onomatope (pembentukan kata yang meniru suara), juga aliterasi berfungsi untuk menyandingkan kata-kata yang keluar dari hubungan semantik biasanya. Kemudian, aliterasi menekankan ritmik dari satu baris dan memberikan tambahan tekanan pada kata yang bersangkutan. Menurut Nayrolles (1996:33) On appelle allitération est la répétition d'une ou plusieurs consonnes à l'intérieur d'un vers. Aliterasi merupakan ppengulangan satu atau beberapa konsonan pada satu larik. Sementara itu menurut Cathrine M.Grisé (2002 : 59) Les consonnes aussi se répètent par des jeux de parallélisme et de symétrie. L'allitération au sens strict du terme est la répétition d'une consonne en tète de mots. Artinya, Konsonan juga diulang dengan permainan paralelisme dan simetri. Dalam arti sempit, aliterasi merupakan pengulangan konsonan pada permulaan kata.

Aliterasi berasal dari bahasa Latin Alliteratio, merupakan majas yang terdiri atas pengulangan satu atau lebih konsonan pada satu larik atau kalimat yang sama. Berikut merupakan contoh aliterasi.

Konsonan terhambat tak bersuara

\section{Tandis qu'autour de tous vos tournois}

[tãdi kotuR də tus vo tuRnwa]

(Verlaine, Cheveaux de Bois dalam antologi Romance Sans Paroles)

Pada contoh pertama, dapat kita lihat adanya repitisi konsonan (aliterasi) untuk fonem [t]. Fonem tersebut termasuk dalam konsonan terhambat dan tidak bersuara, dan alat ucap yang berperan yaitu dental (gigi), sehingga pada saat menyebutkan fonem tersebut akan terdengar seperti letupan pada mulut.

Konsonan terhambat bersuara

François-les-bas-bleus s'en égaie.

[fRãswa le ba blø sã-nege]

(Verlaine, Arièttes Oubliées VI dalam antologi Romance Sans Paroles)

Pada larik puisi di atas ditemukan adanya aliterasi untuk konsonan [b]. Konsonan tersebut termasuk dalam jenis konsonan yang terhambat dan bersuara dengan alat ucap 
Icha Priliskha Y., Nurul Hayana, Yuliarti Mutiarsih, Gaya Bahasa Asonansi dan Aliterasi pada Antologi Puisi Romances Sans Paroles

yang digunakan adalan bibir (labial). Cara pengucapannya yaitu dengan mengatupkan kedua bibir lalu membukanya sedikit.

Konsonan geseran tak bersuara

C'est ravissant comme ça vous soûle

[se Ravisãa kom sa vu sul]

(Verlaine, Cheveaux de Bois dalam antologi Romance Sans Paroles)

Larik di atas menunjukkan pengulangan pada konsonan [s]. Fonem tersebut merupakan bagian dari jenis konsonan yang bergeser dan tidak bersuara, suara yang dihasilkan akan terletak pada alveolar. Cara mengucapkan kosonan ini adalah seperti mendesis.

Konsonan geseran bersuara

Et voici venir La Ramée

[e vwasi vəniR la Rame]

(Verlaine, Arièttes Oubliées VI dalam antologi Romance Sans Paroles)

Penggalan larik di atas terlihat adanya pengulangan konsonan dari jenis konsonan geseran bersuara $[\mathrm{v}]$. Pengucapan konsonan [v] menggunakan bagian mulut bibir dan juga gigi maka dari itu fonem [v] termasuk dalam jenis pengucapan labiodental.

Konsonan geseran sampingan

Est-il possible, - le fût-il - Ce fier exil, ce triste exil ?

[ع-til posibl lə fy-til sə fjeR عgzil sə tRist $\varepsilon g z i l]$

(Verlaine, Arièttes Oubliées VI dalam antologi Romance Sans Paroles)

Pada larik tersebut terlihat adanya pengulangan dari konsonan geseran sampingan [1], dengan pengucapan menggunakan alveolar yaitu lidah menyentuh bagian alveolar. Permukaan lidah agak sedikit cembung dan menimbulkan hambatan di tengah alveolar (langit-langit) dan pada saat diucapkan terasa adanya udara yang lewat melalui dua sisi lidah.

Konsonan geseran bergetar

Cela se comprend par malheur, de reste. 
[səla sə kõpRõ paR malø $\underline{\mathrm{R}}$ də $\underline{\mathrm{R}} \varepsilon s]$

(Verlaine, Birds In The Night dalam antologi Romance Sans Paroles)

Larik di atas berisi aliterasi konsonan [R] yang juga dari jenis konsonan geseran bergetar. Fonem [R] merupakan jenis bunyi dengan pengucapan melalui dorsovelar yaitu suara getar yang dihasilkan merupakan getaran pada anak tekak yang menempel di belakang lidah atau di sekitar tenggorokan.

\section{Semi konsonan}

Des messieurs bien mis, sans nul doute amis [de mesఏø bjẽ mi sã nyl dut ami]

(Verlaine, Simple Fresque dalam antologi Romance Sans Paroles) Larik di atas berisi aliterasi semi konsonan [j]. Fonem tersebut termasuk dalam kategori patal yaitu dengan pengucapan dengan saluran antara lidah dan langit-langit yang sempit, agar terdengar sedikit bunyi karena hambatan yang dihasilkan.

\section{Simpulan}

Penelitian ini menunjukkan adanya perbedaan beberapa jenis fonem vokal maupun kosonan antara bahasa Prancis dan Indonesia yang menjadi penyebab kesulitan bagi pembelajar Indonesia untuk mengucapkan kata-kata dalam bahasa Prancis, berawal dari kesulitan yang dirasakan lambat laun akan menyebabkan kesalahan pengucapan. Kesalahan dalam pengucapan juga dilakukan saat pembacaan puisi yang membutuhkan ekspresi yang tepat dalam resitasi puisi. Harmonisasi dalam puisi tidak hanya terdapat pada maknanya, tetapi juga dalam penyusunan huruf demi huruf agar menimbulkan keindahan pada tekanan dan pengucapannya. Gaya bahasa asonansi dan aliterasi kerap digunakan dalam penyusunan larik demi larik dalam karya puisi. Repitisi dari suatu hurudhuruf mampu menambah keindahan dalam penekanan suara saat pembacaan berlangsung.

Berdasarkan analisis yang dilakukan, dapat disimpulkan bahwa gaya bahasa asonansi dan aliterasi ditemukan di seluruh judul puisi. Harmonisasi yang terdapat pada puisi dihasilkan oleh efek-efek fonem yang berbeda jenisnya. Seperti yang terjadi pada pengulangan konsonan atau aliterasi dari fonem jenis geseran bergetar [R] yang menjadi dominan pada antologi puisi Romances sans Paroles karya Paul Verlaine. 
Asonansi dan aliterasi digunakan pada puisi dan keduanya berfungsi untuk meningkatkan harmoni imitasi. Dari enam belas data yang dianalisis, ditemukan 61 asonansi dan 76 aliterasi. Data didominasi oleh fonem [R] yang ditemukan sebanyak 11 kali.

\section{Daftar Pustaka}

Chaer, Abdul. 2007. Linguistik Umum. Jakarta : Rineka Cipta.

Grisé, Cathrine M. 2002. Rencontres Avec La Poésie. Toronto: Canadian Scholar's Press Inc.

Nayrolles, Françoise. 1996. Pour Étudier Un Poème. Paris: Hatier.

Peyroutet, Claude. 1994. Style et Rhétorique. Paris: Nathan.

Polili, Andi Wete. et Fibriasari, Hesti. 2013. Audition Prononciation. Medan: Universitas Negeri Medan.

Pierre. et Léon Monique. Introduction à la Phonétique Corrective. Canada: Université de Toronto.

Tamine, Joëlle Gardes. La Grammaire. 1/ Phonologie, morphologie, lexicologie. Paris: Armand Colin.

Schmit, M.P. et Viala, A. 1982. Savoir-lire. Paris: Les Édition Didier.

Vaillant, A. 2005. La poésie: Initiation Aux Méthodes D’analyse Des Textes Poétiques. Paris: Armand Colin.

Varga, A. Kibedi. 1971. Le poème et ses lectures. $\mathrm{N}^{\circ} 23$. Juli 2020. http://www.persee.fr/doc/caief 0571-5865 1971_num 23 1 977. Diakses pada 1

Verlaine, Paul. 1874. Romances sans Paroles. Paris:Lepelletier.

Waluyo, Herman J. 2002. Apresiasi Puisi. 2002. Jakarta: Gramedia Pustaka. 